,

\title{
Urbanization Impacts on Houston Rainstorms
}

\author{
Steven J. Burian, J. Marshall Shepherd and Parastou Hooshialsadat
}

During urbanization the natural landscape is altered by removal of indigenous vegetation, stripping of topsoil, modification of the soil profile, importation of fill material, compaction of soil layers, and the introduction of impervious surfaces. These actions alter the hydrologic response at the regional and catchment scales, decreasing travel time of overland flow, infiltration, soil water content, and groundwater recharge, and increasing surface runoff volumes, discharge rates, and pollutant loadings. These are direct and quantifiable impacts to the hydrologic cycle manifested at and below the land surface, but there are other impacts not as well understood or quantifiable that occur through the land surface-atmosphere interface. One such impact is the influence of urban development on mesoscale circulations and resulting convection. Hypothesized mechanisms for urban enhancement of convective rainfall include enhanced convergence caused by the urban heat island, drag effects of the built-up surface, and modified microphysical and dynamical processes caused by the introduction of water and cloud condensation nuclei from automobiles and industry. Decades of accumulated observational and modeling evidence has shown that major cities may indeed be influencing convective activity causingmodified precipitation patterns. This chapter seeks to corroborate these findings by summarizing evidence that the urbanization of a major coastal city in the United States has resulted in modified rainstorm characteristics within the urbanized area and in the seasonally variant downwind urban-affected

Burian, S., M. Shepherd and P. Hooshialsadat. 2004. "Urbanization Impacts on Houston

Rainstorms." Journal of Water Management Modeling R220-01. doi: 10.14796/JWMM.R220-01.

(C) CHI 2004 www.chijournal.org ISSN: 2292-6062 (Formerly in Innovative Modeling of Urban Water Systems. ISBN: 0-9683681-9-0) 
region compared to an upwind control region. It also includes a short summary of the coupling of a meteorological model and SWMM to study in greater detail the potential impact of modified rainstorm characteristics on hydrologic response.

\subsection{Introduction}

Urbanization is known to have significant impacts on the hydrologic cycle. The introduction of impervious surfaces and efficient drainage systems, the removal of vegetative cover, and the disturbance of the soil matrix during construction all have been documented to increase runoff volumes and discharge rates. Pitt et al. (2003) summarized several years of research documenting the reduced infiltration capacity through soils disturbed during urbanization. Scheuler (1994) presented a summary discussion of the role of urban impervious surfaces on stormwater runoff quantity. A literature review of hydrologic impacts of urbanization and the link to stream geomorphology provided numerous documented qualitative case studies, but few with quantitative information describing the phenomena (EPA 1997). In addition to these well-known hydrologic impacts of urbanization, modifications of the land surface-atmosphere interface that occur during urbanization are also influencing the hydrologic cycle. For example, the modification of surface covers during urbanization alters the fluxes of water, momentum, and energy. The observed effects of these altered surface fluxes include changes to the local and regional temperature distributions (Bornstein 1968), wind patterns (Hjemfelt 1982), and air quality (Quattrochi et al. 1998). Urban areas may also impact the global climate through development of clouds and precipitation in and around cities (Changnon 1992).

In the past several decades, observational and climatological studies have provided evidence of urban influence on mesoscale circulations and resulting convection. Horton (1921) noted thunderstorm formation over large cities while there were none over nearby rural areas. Landsberg (1956) reported a $5-15 \%$ increase in precipitation, frequency of rainfall, and numbers of thunderstorms in large cities compared with adjacent rural areas. Changnon (1968) and Atkinson (1968) also noted potential impacts of large urban areas on rainfall patterns. Following the paper describing the La Porte rainfall anomaly by Changnon, a debate evolved regarding the reality of the observed rainfall anomalies within and downwind of urban areas. To test their hypothesis, Changnon et al. (1977) conducted the Metropolitan Meteorological Experiment 
(METROMEX), an extensive study during the mid-1970s in St. Louis, to provide insight into the influence of major urban areas on mesoscale and convective rainfall. This study found that urban effects led to a $5-25 \%$ increase in summer precipitation within and 50-75 km downwind of the city.

Studies continue to validate and extend METROMEX investigations. For example, data analyses by Balling and Brazel (1987) found more frequent late afternoon and early evening storms in Phoenix, Arizona, possibly linked to population growth and the unusual nocturnal wind flows. Shepherd et al. (2002) performed a unique data analysis of rainfall rates measured by the Precipitation Radar aboard the Tropical Rainfall Measuring Mission (TRMM) satellite for the cities of Atlanta, Montgomery, Dallas, Waco, and San Antonio. They found that the average percentage increase in mean rainfall rate in the identified urban impact zone over an upwind control area was $28.4 \%$. Recent numerical modeling studies have also demonstrated the effects of urban environments on the convective boundary layer and enhanced daytime thunderstorm formation (Bornstein and Lin 2000; Thielen et al. 2000; Rozoff et al. 2003; Adegoke, personal communication).

Modified temporal and spatial rainfall patterns in major urban areas have important implications for flood control. Severe thunderstorms and flooding in urban areas disrupts transportation, causes property damage, and may possibly lead to loss of life in extreme cases (Changnon 1996). Flooding of streets impedes automobile and truck traffic and increases the risk of accidents. High winds and lightning associated with thunderstorms can inhibit air traffic, damage structures, and knock out power distribution systems. Of interest from an urban drainage perspective are the heavy rainstorms and the potential of urban areas to enhance the frequency and intensity of such events and consequently exacerbate flooding when not included in planning and design of storm drainage systems and flood control structures.

Several studies have investigated the urban influence on the higher intensity and larger total-accumulated-depth rainstorms. One such study was a component of METROMEX that involved analyses of rainfall data collected by the dense raingage network established within and around St. Louis to determine the impact of urban areas on heavy rainstorms (Huff and Vogel 1978). This work involved the analysis of the distribution of heavy rainstorms (defined as $\geq 25 \mathrm{~mm}$ of rainfall recorded at one of the raingages in the dense network) in seventeen selected areas in and around the St. Louis metropolitan area for a period of five summers. Higher ratios of the normalized volumes of rainfall in the urban area to that of the upwind control area indicated that urban or topographic effects were present and important. This result coupled with 
other work by the authors suggested that the enhanced rainfall volume from heavy rainstorms in the urban-affect areas was due to stimulation of ongoing storms by modification of the dynamics and/or microphysics of cloud processes in the urban area.

Analysis of data from a dense raingage network in northeastern Illinois (including Chicago) for the summers of 1976-1977 suggested that the urban area experienced $176 \%$ more heavy rainstorms $(\geq 25 \mathrm{~mm}$ of rainfall) than the rural control area adjacent to Chicago (Changnon and Semonin 1977). Jauregui and Romales (1996) found that the daytime heat island in Mexico City seemed to correlate with intensification of rain showers during the wet season (MayOctober) and that frequency of intense rain showers had increased in recent decades in connection with the growth of the city. Changnon and Westcott (2002) analyzed 12 y of rainfall data from a dense raingage network in operation in Chicago since 1989 and compared the characteristics of heavy rainstorms to rainstorms that occurred from 1948 to 1980 . Heavy rainstorms were defined as those with an hour or longer (up to 24 hour) duration and an intensity equal to or greater than the published 2-y return-period event. Results indicated that $40 \%$ more heavy storms occurred on average per year from 1989 to 2001 compared to 1948 to 1980 . Furthermore, the spatial distribution of the total rainfall from the heavy storms for the more recent time period was found to be maximized over the city, confirming previous observations of enhanced rainfall in Chicago.

Some studies have expanded on the identification of the rainfall anomaly by translating the modified rainfall patterns to impacts on transportation systems and hydrologic response. Changnon (1996) investigated the impacts of urban heat island enhanced rainfall events in Chicago on transportation systems. Analysis of transportation accident data indicated that on rainy days traffic accidents in the metropolitan area doubled, accident severity was increased, and $57 \%$ of the 30 -min or longer flight delays at Chicago O'Hare Airport occurred. The rainy day influence on transportation accidents and flight delays leads one to the rational correlation between urban-enhanced rainfall activity and increased traffic accidents and flight delays, although research to quantify this relationship has not been performed. Other work by Changnon (1980) defined urban flood events in Chicago to correspond to the 1- to 5-y recurrence-interval rainstorms. This information coupled with previous work by Changnon and Semonin (1977) that found from 14 to $176 \%$ more heavy rain events in the 1- to 4-y return periods occurred due to urban influences in Chicago suggested that Chicago flooding events were being increased from 10 to $100 \%$ due to urban effects. 
The objectives of this chapter are to summarize the evidence of urbanization impact on rainstorms in Houston, Texas and to briefly present the coupling of a meteorological model to the US EPA (US Environmental Protection Agency) Storm Water Management Model (SWMM) to investigate the hydrologic response to urban-enhanced convective rainfall events. The next section of the chapter summarizes previous work documenting the urban-induced rainfall anomalies in Houston and present new evidence of the urban effect on storm event characteristics. The final section summarizes the chapter and describes future work.

\subsection{Influence of Houston Urban Area on Rainfall}

\subsubsection{Background}

Houston currently has a population of 1.9 million, ranking it as the fourth largest city in the U.S. The Houston Urbanized Area, as defined by the U.S. Census Bureau in 2000, has a population of 3.8 million, while the entire HoustonGalveston-Brazoria Consolidated Metropolitan Statistical Area (CMSA) has a population of 4.8 million. The Houston Urbanized Area encompasses approximately $3350 \mathrm{~km}^{2}$ of the Gulf Coastal Plain with a high elevation of about $27 \mathrm{~m}$ above mean sea level. Houston's climate is subtropical humid with very hot and humid summers and mild winters. In summer, the average maximum daytime temperature is $34^{\circ} \mathrm{C}$ while in winter the temperature averages between 4 and $16^{\circ} \mathrm{C}$. Humidity is the greatest in the late summer and early fall, reaching a peak in July and August when the average dewpoint temperature is $22^{\circ} \mathrm{C}$. Average annual rainfall recorded at the Bush International Airport for the past two decades is $1200 \mathrm{~mm}$. Analysis of thunderstorm day and rainfall amount data stratified by month suggests that rainfall during the summer months (June, July, and August) is dominated by sub-tropical convection, while spring and fall months (March, April, May, September, and October) contains a mixture of convective and frontal storms, and the winter months (November, December, January, and February) are dominated by frontal storms.

Previous investigations of urban effects on Houston rainfall have led to different conclusions ranging from no effect to a significant effect. Kelly (1972) analyzed 58 y of annual rainfall data from 22 raingages distributed throughout Southeast Texas to determine if the data recorded by the Houston Weather Station were statistically different than the data from nearby rural gages. Fourier analysis of that data indicated no significant difference between the 
rainfall trend at the Houston station, compared to the other stations. Additional analyses were performed on data from a 12-gage Houston area rainfall network to determine monthly and annual spatial patterns for 1955-1970. The spatial patterns did not reveal a discernible maximum over the urban area. The rainfall patterns were also analyzed in conjunction with data from the Houston air pollution monitoring network to determine if increased air pollution was altering rainfall patterns. The analyses found no significant alteration of rainfall patterns due to air pollution.

Huff and Changnon (1973) studied weather records in eight U.S cities including Houston for indications of urban effects on rainfall. Their analyses of historical Houston data showed little evidence of an urban effect on monthly or seasonal rainfall patterns. However, a $17 \%$ increase in rainfall from non-frontal storms within the city during the warm season (June - August) from 1964-1968 was found relative to areas outside the city. Analyses of thunder days and hail days related to growth of the Houston industrial sector suggested a possible urban-industrial effect on thunderstorms in the area of industrial growth.

Data from 26 Houston area raingages for the period 1901 to 1973 were analyzed by Crooker and Goldman (1974). Annual precipitation isohyets revealed significant precipitation modification along the axis of the mean annual near surface wind direction. This was attributed to urban development. Bouvette et al. (1982) developed revised intensity-duration-frequency relationships for four Houston area raingages based on data up to 1981 and compared the revised intensities with those developed in 1961 by the U.S Weather Bureau (Hershfield 1961). The 24-h, 100-y storm intensity had decreased by $13 \%$ from 1961 to 1981 for the downtown gage, but had increased by an average of $15 \%$ for the three gages in developing areas.

A recent analysis of 12 y (1989-2000) of ground-based lightning data for the Houston area indicated that the highest flash densities recorded were over and downwind of the Houston area (Orville et al. 2001). Mesoscale model simulations suggested that the elevated lightning densities were caused by either urban heat island-induced convergence or enhanced lightning efficiency by increased urban aerosols, or some combination of these effects. Since lightning is associated with convection in the atmosphere, the urban modification of lightning patterns suggests that the urban area is also impacting rainfall.

\subsubsection{Downscaling Analysis}

A downscaling analysis of Houston rainfall data was performed to identify and quantify Houston rainfall anomalies (HRA) at multiple space and time scales. 
The analysis involved much longer and more complete rainfall datasets than have been used previously for Houston. The downscaling process involved three steps:

1. define the upwind control region (UCR), urban area (UA), and the urban impacted region (UIR) based on identifying the likely location of urban effects and the direction of the mean $700 \mathrm{hPa}$ steering flow (see Shepherd et al. 2002);

2. analyze TRMM precipitation radar-derived (PR) rainfall rates within the UCR, UA, and UIR and identify anomalies; and

3. downscale in space and time by using ground-based radar and raingage data to analyze at a finer resolution the urban impact and spatial and temporal patterns.

The Houston urban core area is located near Galveston Bay, approximately $80 \mathrm{~km}$ inland from the Gulf of Mexico. The prevailing near-surface wind flow is predominantly southeasterly, driven by the sea breeze. The steering flow at the $700 \mathrm{hPa}$ level was found by analyzing the robust climatological record of the NCAR-NCEP re-analysis dataset on an annual and seasonal basis. The mean annual reference coordinate system was aligned along the mean steering flow wind vector at $230^{\circ}$ (southwesterly) and the mean warm season (June - August) reference coordinate system was aligned along the wind vector at $178^{\circ}$ (southerly) (see Figure 1.1). Previously observed rainfall anomalies in other cities have been found 50-100 km downwind of the urban center. Therefore, for the annual coordinate system the UIR was extended approximately $150 \mathrm{~km}$ from the northeastern edge of the UA in the seasonal downwind direction to
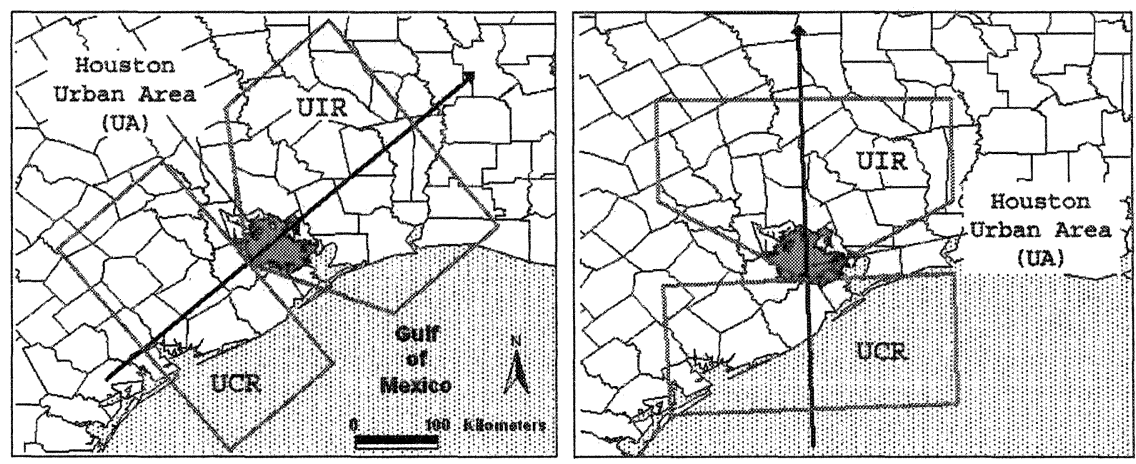

Figure 1.1 Reference coordinate systems for the Houston downscaling analysis. The black vector in the left coordinate system corresponds to the mean annual steering flow $\left(230^{\circ}\right)$ and in the right system corresponds to the mean warm season steering flow $\left(178^{\circ}\right)$. 
ensure capture of rainfall anomalies. The UCR extends an equal distance upwind of the southwestern edge of the UA. The UIR includes a $125^{\circ}$ sector to account for the variability of the wind direction. The warm season coordinate system was developed similarly using the mean warm season wind vector as the reference axis. Further details about the derivation of the reference coordinate system for Houston can be found in Shepherd and Burian (2003). The TRMM $P R$ and raingage data within the UCR, UA, and UIR as defined by the reference coordinate systems were analyzed for rainfall anomalies.

\subsubsection{TRMM PR Data Analysis}

Shepherd and Burian (2003) presented the results from the TRMM PR component of the downscaling analysis for Houston. The analysis of the mean monthly "conditional" rainfall rates recorded by the TRMM PR at a height of $2 \mathrm{~km}$ supported the hypothesis that the central Houston urban area and the seasonally-variant downwind regions (generally northeast for Houston, but northwest-northeast during the warm season) exhibit enhanced rainfall relative to regions upwind of the city. The mean monthly rainfall rate was computed to be $2.97 \mathrm{~mm} / \mathrm{h}$ in the UIR, $2.66 \mathrm{~mm} / \mathrm{h}$ in the UA, and $2.06 \mathrm{~mm} / \mathrm{h}$ in the UCR for the annual coordinate system. This represents an increased mean rain rate of $44 \%$ in the UIR and $29 \%$ in the UA compared to the UCR. The results were more dramatic in the UA for the warm season analysis. The mean monthly rain rate during the warm season was increased by $28 \%$ in the UIR and $57 \%$ in the UA. Results corroborated the findings from the Orville et al. (2001) Houston lightning study, and they confirmed analyses conducted by Huff and Changnon (1973) and Bouvette et al. (1982). The study also presented evidence that the HRAs are linked to the urbanized region and not exclusively sea or bay breeze circulations.

\subsubsection{Raingage Data Analysis}

The third step in the downscaling analysis approach was to analyze higher spatial and temporal resolution datasets to flesh out the HRAs identified within and nearby the urban area by the TRMM PR data analyses. Raingage data were obtained from the National Climatic Data Center (NCDC) and the City of Houston Office of Emergency Management for all raingages located within 250 $\mathrm{km}$ of the Houston urban center (469 gages). The NCDC data were available in increments ranging from 15-min to daily, and the Houston data were available in inconsistent short increments based on the conversion of the tip count to 
Table 1.1 Number of raingages in the UCR, UA, and UIR.

\begin{tabular}{cccccc}
\hline & & \multicolumn{2}{c}{ Annual } & \multicolumn{2}{c}{ Warm Season } \\
\cline { 3 - 6 } & $\begin{array}{c}\text { Area } \\
\left(\mathrm{km}^{2}\right)\end{array}$ & $\begin{array}{c}\text { Number of } \\
\text { Gages }\end{array}$ & $\begin{array}{c}\text { Gage Density } \\
\left(\text { per } 10^{3} \mathrm{~km}^{2}\right)\end{array}$ & $\begin{array}{c}\text { Number of } \\
\text { Gages }\end{array}$ & $\begin{array}{c}\text { Gage Density } \\
\left(\text { per } 10^{3} \mathrm{~km}^{2}\right)\end{array}$ \\
UCR & 27,500 & 26 & 1.0 & 21 & 0.8 \\
UA & 3,000 & 57 & 19.0 & 62 & 20.7 \\
UIR & 31,000 & 38 & 1.2 & 40 & 1.3 \\
\hline
\end{tabular}

rainfall depth. The rainfall records obtained were screened and those with inadequate data coverage (more than $10 \%$ missing data) for the time period of 1984-1997 were removed from the data pool. Also, any year with more than one continuous month of data missing was removed from the record, but the remainder of the record was still included in the analysis. This second screening criterion was applicable to a small fraction of the gages used in the analysis. Finally, hurricane and tropical storm events were removed from the records. Table 1.1 lists the approximate size of the three coordinate system regions and the number of raingages that met the necessary constraints for inclusion in the study. Note the much higher gage density in the urban area compared to the other two regions.

The mean annual and warm season rainfall amounts were determined for each raingage and averaged within each region. The average and standard deviation of the means within each region are shown in Table 1.2. Based on these means, the UIR has had $24 \%$ greater average annual rainfall than the UCR for the 1984 to 1997 time period. The UA has had a $12 \%$ greater average annual and a $22 \%$ greater average warm season rainfall from 1984 to 1997 . These differences between the means are each significant at the 5\% level according to the Wilcoxon Rank Sum test and the Student $t$ test. It is interesting to note that during the warm season the UA has much greater rainfall than the UCR, but the rainfall in the UIR shows smaller differences from the UCR. This observation is consistent with TRMM PR data analysis that showed that on an

Table 1.2 Mean and standard deviation of average annual rainfall amounts recorded at gages within UCR, UA, and UIR. Statistics based on $14 \mathrm{y}$ of record (1984-1997).

\begin{tabular}{lcccc}
\hline & \multicolumn{2}{c}{ Annual } & \multicolumn{2}{c}{ Warm Season } \\
\hline & Mean & St. Dev. & Mean & $\begin{array}{c}\text { St. Dev. } \\
(\mathrm{mm})\end{array}$ \\
UCR & $(\mathrm{mm})$ & $(\mathrm{mm})$ & $(\mathrm{mm})$ & 45 \\
UA & 1070 & 140 & 274 & 26 \\
UIR & 1201 & 95 & 333 & 63 \\
\hline
\end{tabular}


annual basis the UIR had the greatest difference from the UCR, but during the warm season the UA had the greatest difference. Thus, the rainfall rates and the rainfall amounts that occurred during the warm season in the UA are much different than the rates and amounts in the UCR. This suggests the rainfall modification in Houston is linked to a summer phenomenon, possibly convective events influenced by the urban heat island.

To further analyze the annual and warm season rainfall differences between the urban-affected region and the upwind control region, the urbanrainfall ratio (URR) described by Shepherd et al. (2002) was computed for each raingage included in the study. The URR is:

where:

$$
U R R_{i}=R_{i} / R_{B G}
$$

$$
\begin{aligned}
R_{i}= & \text { the mean annual (or warm season) rainfall amount at } \\
& \text { raingage } i \text { over the 14-y period, and } \\
R_{B G}= & \text { the mean background rainfall amount over the entire } \\
& \text { UCR-UA-UIR domain over the 14-y period. }
\end{aligned}
$$

The URR indicates the relative magnitude of the mean annual rainfall amount at each raingage compared to a background value. Figures 1.2 and 1.3 display the plots of the annual and warm season $U R R$ values, respectively, plotted in no particular order. An interesting observation is the appearance of

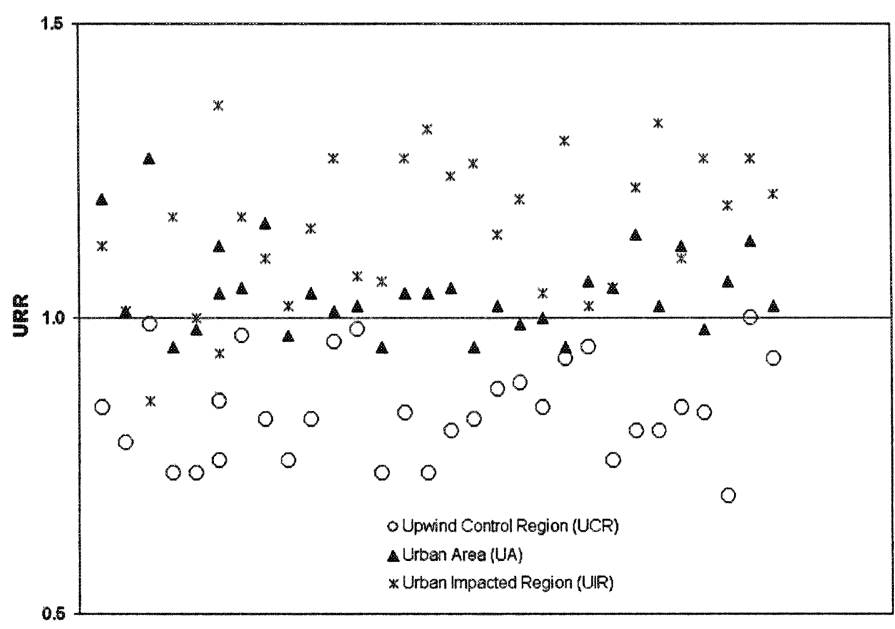

Figure 1.2 Plot of annual raingage URR values. 


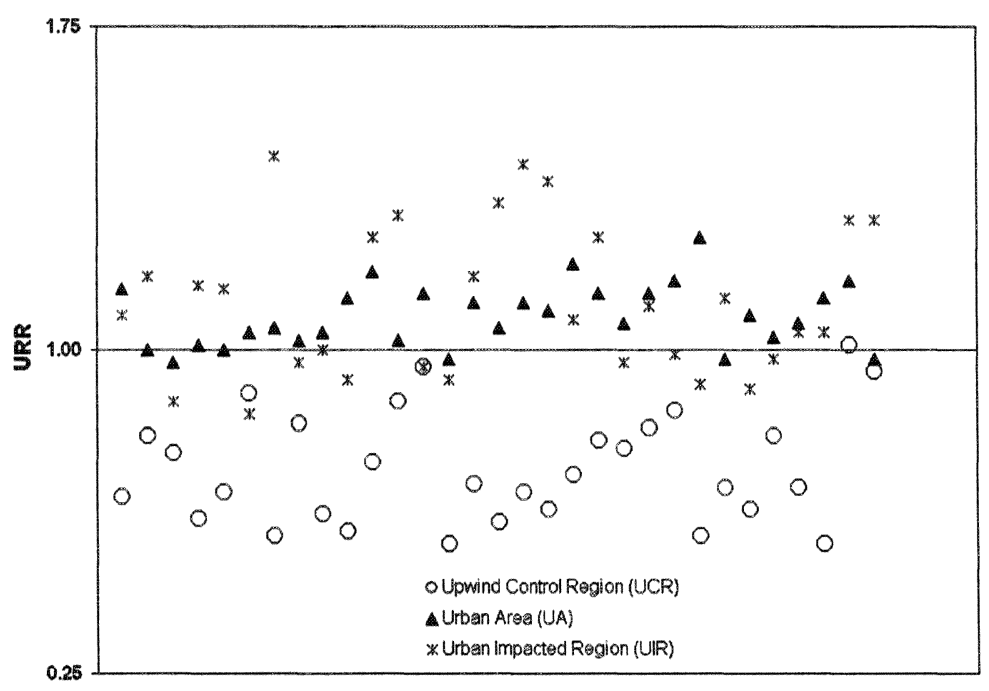

Figure 1.3 Plot of warm season raingage URR values.

a possible increasing rainfall gradient from southwest to northeast on an annual basis that is not observed during the warm season. The upwind region had $97 \%$ of the annual URR values less than 1.0 (i.e. smaller than background), while the UA (UIR) had $61 \%(90 \%)$ of the annual ratios greater than 1.0 . The fraction of URRs greater than 1.0 increases from the southwest to northeast direction for the annual rainfall amounts. During the warm season, however, the UA has a higher fraction of URRs greater than $1.0(86 \%)$ compared to the UIR (61\%) inconsistent with the notion of a southwest to northeast increasing rainfall gradient. The warm season URR trend further supports the evidence presented above suggesting a warm season urban effect on rainfall in Houston.

The analysis of TRMM PR and raingage data has demonstrated differences in mean rain rates and amounts in the UIR and UA compared to the UCR. To further confirm that the observed differences are indeed an urban effect, an analysis of storm event characteristics during a relatively "pre-urban" time period in Houston and a "post-urban" time period was conducted. The preurban time period chosen for Houston was 1940-1958 and the post-urban time period was selected to be 1984-1999. Houston was transforming during the pre-urban time period into a major industrial and population center, but the extent of the urban area was still relatively small compared to the present size of the city. Therefore, the urban influence on rainfall, if present, is expected to be much less during the pre-urban time period than during the post-urban time 
period. Due to natural background climate variability, comparing the pre-urban to post-urban time periods for each raingage, or for averages of raingages in each zone, might not provide useful information. Rather, interest lies in comparing the relative changes in the rainfall characteristics in the UA from preurban to post-urban to those observed in the upwind control region. The hypothesis is that if the urban effect is present, more significant rainstorm characteristic changes will be observed in the urban-affected region (UAR) compared to the UCR.

The rainstorm event analysis required dividing the long-term rainfall records into statistically independent storm events. It was not feasible to inspect the meteorology over the $30+$ years of record for an area of several thousand square kilometers to help identify separate events from a meteorological perspective. Instead procedures were performed to determine the minimum interevent time (MIT) of dry weather that separates statistically independent rainstorms (Adams and Papa 2000; Restrepo-Posada and Eagleson 1982). The records from two rain gages in Houston were chosen for MIT determination, one located to the north of the city center and one to the south. The rainfall records were subjected to three analyses: (i) plots were constructed of the number of events versus the MIT, (ii) the autocorrelation function for the rainfall time series was determined, and (iii) the coefficient of variation of rainfall statistics was determined for different MITs. The battery of tests provided a range for selecting an MIT, but did not indicate a single value. The range of MIT for annual rain records was determined to be between about 7 to $15 \mathrm{~h}$ according to interpretation of the three test results. An MIT of $10 \mathrm{~h}$ was chosen to best represent the cumulative information from the tests. An MIT of $10 \mathrm{~h}$ should separate the short intense convective storm events that might occur on successive days, while not separating single events with short periods of no rainfall accumulation recorded within the event.

The raingages used in this part of the study had to have less than $10 \%$ of total data missing from the two periods (1940-1958 and 1984-1999) and had to be in hourly or less time increments (i.e. daily records were not included). Once again, a year of record would be removed if more than one continuous month of data were missing and hurricane and tropical storm events were removed. From the 469 raingages available for analysis, nine met the necessary criteria. The locations of the nine gages are shown in Figure 1.4. For the storm event analysis two regions were used because of the limited data: an urbanaffected region and the upwind control region. For the annual analysis, the urban-affected region (UAR) included gages 4309 and 4311 in the city, as well as 7174 and 3430 , while the UCR was represented by $569,9364,1671,5193$, 


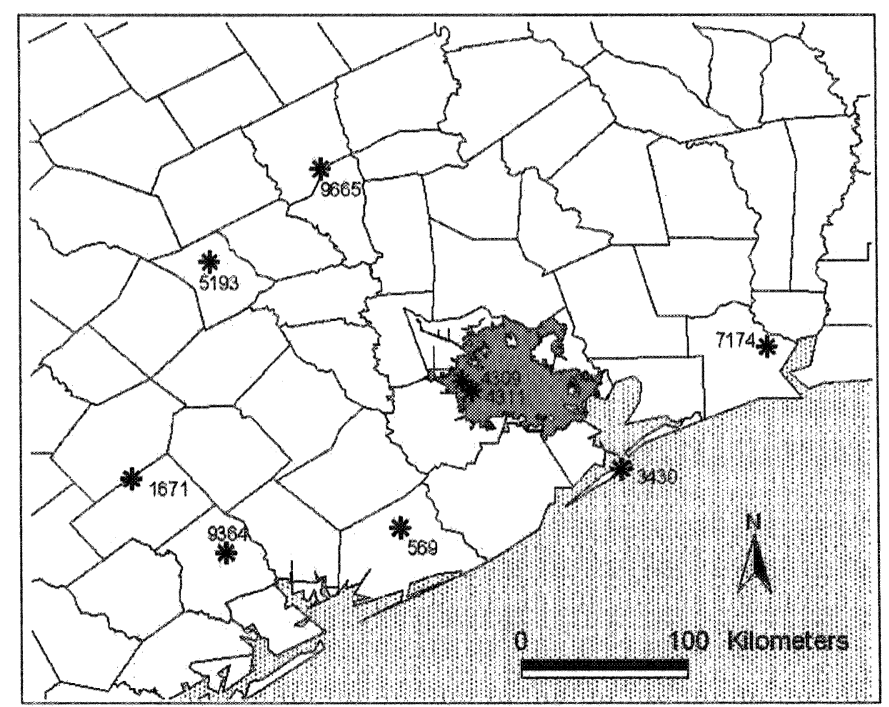

Figure 1.4 Raingages selected for pre-urban and post-urban rainstorm comparisons.

and 9665 . During the warm season the mean wind direction changes (see Figure 1.1 ) and the UAR then includes gages $4309,4311,5193,7174$, and 9665 , while the UCR includes $3430,569,9364$, and 1671 .

The rainfall records were processed using the US EPA Storm Water Management Model (SWMM) (Huber and Dickinson 1988) RAIN module using a 10-h MIT. Table 1.3 shows the rainstorm characteristics for the UAR and UCR for pre- and post-urban time periods. The statistics in Table 1.3 indicate that the average rainstorm characteristics in both time periods are fairly similar between the UAR and UCR when averaged for the entire year. One primary difference is more storm events occur on average in the UAR than the $\mathrm{UCR}$, but this difference is present in the pre- and post-urban time periods. Another difference is the magnitude of decrease in the average storm event duration in the UCR $(-37 \%)$ and UAR $(-5 \%)$ from the pre- to post-urban time periods. The decrease in average event duration is accompanied by increases in average event intensity in both the UAR and UCR. The decreased duration and increased intensity essentially cancel and the average event volume remains the same. The average event maximum 1 -h intensity is identical in the UAR and UCR for both time periods, with a modest $16 \%$ increase observed from the pre- to post-urban time period for both the UAR and UCR. Table 1.4 displays the storm event characteristics for the warm season (June-August). Again a trend of 


\begin{tabular}{lcccccccccc}
\hline & $\begin{array}{c}\text { Average Annual } \\
\text { Number of Events }\end{array}$ & $\begin{array}{c}\text { Average Storm Event } \\
\text { Volume }(\mathrm{mm})\end{array}$ & $\begin{array}{c}\text { Average Storm Event } \\
\text { Intensity }(\mathrm{mm} / \mathrm{h})\end{array}$ & $\begin{array}{c}\text { Average Storm Event } \\
\text { Max 1-h Intensity } \\
(\mathrm{mm} / \mathrm{h})\end{array}$ & $\begin{array}{c}\text { Average Storm Event } \\
\text { Duration }(\mathrm{h})\end{array}$ \\
\hline & UAR & UCR & UAR & UCR & UAR & UCR & UAR & UCR & UAR & UCR \\
$\begin{array}{l}\text { Pre-urban } \\
\begin{array}{l}\text { Post- } \\
\text { urban }\end{array}\end{array}$ & 71.1 & 56.4 & 15.2 & 15.0 & 2.29 & 2.54 & 6.60 & 6.60 & 7.9 & 8.6 \\
$\%$ change & 73.3 & 64.0 & 16.8 & 15.0 & 3.05 & 3.56 & 7.62 & 7.62 & 7.5 & 5.4 \\
\hline
\end{tabular}

Table 1.4 Warm season pre- and post-urban rainstorm characteristics in the UAR and UCR.

\begin{tabular}{lcccccccccc}
\hline & $\begin{array}{c}\text { Average Annual } \\
\text { Number of Events }\end{array}$ & \multicolumn{2}{c}{$\begin{array}{c}\text { Average Storm Event } \\
\text { Volume }(\mathrm{mm})\end{array}$} & $\begin{array}{c}\text { Average Storm Event } \\
\text { Intensity }(\mathrm{mm} / \mathrm{h})\end{array}$ & $\begin{array}{c}\text { Average Storm Event } \\
\text { Max 1-h Intensity } \\
(\mathrm{mm} / \mathrm{h})\end{array}$ & $\begin{array}{c}\text { Average Storm Event } \\
\text { Duration (h) }\end{array}$ \\
\hline & UAR & UCR & UAR & UCR & UAR & UCR & UAR & UCR & UAR & UCR \\
$\begin{array}{l}\text { Pre-urban } \\
\begin{array}{l}\text { Post- } \\
\text { urban }\end{array}\end{array}$ & 16.2 & 17.0 & 15.0 & 14.7 & 3.37 & 3.15 & 7.60 & 7.43 & 5.8 & 5.9 \\
$\%$ change & 18.2 & 18.7 & 14.5 & 12.7 & 4.28 & 3.92 & 8.83 & 7.71 & 4.8 & 4.3 \\
\hline
\end{tabular}


Table 1.5 Annual pre- and post-urban "heavy" rainstorm characteristics in the UAR and UCR.

\begin{tabular}{lcccccccccc}
\hline & $\begin{array}{c}\text { Average Annual } \\
\text { Number of Events }\end{array}$ & $\begin{array}{c}\text { Average Storm Event } \\
\text { Volume }(\mathrm{mm})\end{array}$ & $\begin{array}{c}\text { Average Storm Event } \\
\text { Intensity }(\mathrm{mm} / \mathrm{h})\end{array}$ & $\begin{array}{c}\text { Average Storm Event } \\
\text { Max 1-h Intensity } \\
(\mathrm{mm} / \mathrm{h})\end{array}$ & $\begin{array}{c}\text { Average Storm Event } \\
\text { Duration (h) }\end{array}$ \\
\hline \multirow{3}{*}{$\begin{array}{l}\text { Pre-urban } \\
\text { Post-urban }\end{array}$} & UAR & UCR & UAR & UCR & UAR & UCR & UAR & UCR & UAR & UCR \\
$\%$ change & 13.0 & 10.4 & 55.9 & 50.6 & 5.33 & 4.89 & 20.77 & 19.09 & 18.1 & 20.1 \\
\hline
\end{tabular}

Table 1.6 Warm season pre- and post-urban "heavy" rainstorm characteristics in the UAR and UCR.

\begin{tabular}{|c|c|c|c|c|c|c|c|c|c|c|}
\hline & \multicolumn{2}{|c|}{$\begin{array}{l}\text { Average Annual } \\
\text { Number of Events }\end{array}$} & \multicolumn{2}{|c|}{$\begin{array}{l}\text { Average Storm Event } \\
\text { Volume }(\mathrm{mm})\end{array}$} & \multicolumn{2}{|c|}{$\begin{array}{l}\text { Average Storm Event } \\
\text { Intensity }(\mathrm{mm} / \mathrm{h})\end{array}$} & \multicolumn{2}{|c|}{$\begin{array}{l}\text { Average Storm Event } \\
\text { Max 1-hr Intensity } \\
(\mathrm{mm} / \mathrm{h})\end{array}$} & \multicolumn{2}{|c|}{$\begin{array}{c}\text { Average Storm Event } \\
\text { Duration (h) }\end{array}$} \\
\hline & UAR & UCR & UAR & UCR & UAR & UCR & UAR & UCR & UAR & UCR \\
\hline Pre-urban & 2.6 & 2.9 & 49.9 & 52.7 & 7.91 & 5.93 & 22.18 & 21.69 & 11.9 & 13.9 \\
\hline Post-urban & 3.5 & 2.8 & 42.6 & 44.1 & 8.38 & 7.91 & 23.96 & 23.02 & 10.1 & 10.3 \\
\hline$\%$ change & $+35 \%$ & $-3 \%$ & $-15 \%$ & $-16 \%$ & $+6 \%$ & $+33 \%$ & $+8 \%$ & $+6 \%$ & $-15 \%$ & $-26 \%$ \\
\hline
\end{tabular}


decreasing average event durations is found accompanied by an increase in average event intensities resulting in relatively similar average event volumes. One notable difference related to urban effects is the $16 \%$ increase in the average event maximum 1 -h intensity in the UAR compared to a $4 \%$ increase in the UCR, suggesting a possible urban enhancement of warm season maximum rainstorm intensities.

The same set of average storm event characteristics (number of events, volume, intensity, maximum intensity, and duration) were determined for "heavy" rainstorms. "Heavy" rainstorms were defined as those with $25 \mathrm{~mm}$ or greater total depth recorded at the raingage. These heavy storms have the potential to cause severe flooding and also have been shown to be affected by urban areas in other cities (e.g. Huff and Vogel 1978). Table 1.5 presents the average annual heavy storm event characteristics. Similar to averages for all storms, the heavy storms also decreased in duration significantly from pre- to post-urban in the UCR, but did not decrease to a great degree in the UAR. The number of heavy storms increased in the UAR by $22 \%$, but only increased by $14 \%$ in the UCR. The significant decrease in duration in the UCR was counteracted by a strong increase in average event intensity leading to no change in average storm event volume. Table 1.6 shows the average heavy rainstorm characteristics for the warm season months. The storm durations once again have decreased from pre- to post-urban time periods, but most storm event characteristics are fairly similar in the UAR and UCR. One major difference is the number of heavy rainstorms occurring on average during the warm season. A 35\% increase (approximately one additional event) in heavy rainstorms was found in the UAR between the pre- and post-urban time periods, while a small decrease of $-3 \%$ was noted in the UCR. The $35 \%$ increase in heavy rainstorms is consistent with the $40 \%$ increase of heavy rainstorms found by Changnon and Westcott (2002) for Chicago, although their definition of "heavy" is different. This change in the UAR heavy storm characteristics, which is not found in the UCR, suggests that the urban effect may be to create more heavy rainstorms. This may be caused by the enhancement of existing storms that would not register as heavy without the urban effect.

The major differences noted in the warm season rainstorm characteristics between the UAR and the UCR were tested for statistical significance using the Wilcoxon Rank Sum test and the Student $t$ test. Table 1.7 presents the results from the statistical comparison of the means. Comparisons were made for the mean average warm season 1 -h maximum rainfall intensity and the mean average warm season number of heavy storm events for the pre-urban and post-urban time periods for the UAR and UCR. 
Table 1.7 Summary of statistical testing of significance of differences between UAR and UCR mean rainstorm characteristics.

\begin{tabular}{|c|c|c|c|c|}
\hline & $\begin{array}{l}\text { Data Series } \\
\text { Comparison }\end{array}$ & $\begin{array}{c}\text { Two-Sample } \\
\text { Test }\end{array}$ & $\begin{array}{c}\text { Significance } \\
\text { Level }\end{array}$ & $\begin{array}{c}\text { Mean } \\
\text { Statistically } \\
\text { Different? }\end{array}$ \\
\hline \multirow{15}{*}{$\begin{array}{c}\text { Average Warm } \\
\text { Season Maximum } \\
\text { 1-h Rainfall } \\
\text { Intensity (All } \\
\text { Storm Events) }\end{array}$} & \multirow{4}{*}{$\begin{array}{l}\text { Pre-Urban } \\
\text { UAR vs. UCR }\end{array}$} & \multirow{2}{*}{ t Test } & $5 \%$ & No \\
\hline & & & $1 \%$ & No \\
\hline & & \multirow{2}{*}{ Wilcoxon } & $5 \%$ & No \\
\hline & & & $1 \%$ & \\
\hline & \multirow{4}{*}{$\begin{array}{l}\text { Post-Urban } \\
\text { UAR vs. UCR }\end{array}$} & \multirow{2}{*}{ t Test } & $5 \%$ & Yes \\
\hline & & & $1 \%$ & No \\
\hline & & \multirow{2}{*}{ Wilcoxon } & $5 \%$ & Yes \\
\hline & & & $1 \%$ & No \\
\hline & \multirow{4}{*}{$\begin{array}{l}\text { UAR Pre- } \\
\text { Urban vs. Post- } \\
\text { Urban }\end{array}$} & \multirow{2}{*}{ t Test } & $5 \%$ & Yes \\
\hline & & & $1 \%$ & No \\
\hline & & \multirow{2}{*}{ Wilcoxon } & $5 \%$ & Yes \\
\hline & & & $1 \%$ & Yes \\
\hline & \multirow{3}{*}{$\begin{array}{l}\text { UCR Pre-Urban } \\
\text { vs. Post-Urban }\end{array}$} & t Test & $5 \%$ & No \\
\hline & & \multirow{2}{*}{ Wilcoxon } & $5 \%$ & No \\
\hline & & & $1 \%$ & No \\
\hline \multirow{15}{*}{$\begin{array}{l}\text { Average Warm } \\
\text { Season Number of } \\
\text { Heavy Rainfall } \\
\text { Events }(>25 \mathrm{~mm})\end{array}$} & \multirow{4}{*}{$\begin{array}{l}\text { Pre-Urban } \\
\text { UAR vs. UCR }\end{array}$} & \multirow{2}{*}{ t Test } & $5 \%$ & No \\
\hline & & & $1 \%$ & No \\
\hline & & \multirow{2}{*}{ Wilcoxon } & $5 \%$ & No \\
\hline & & & $1 \%$ & No \\
\hline & \multirow{4}{*}{$\begin{array}{l}\text { Post-Urban } \\
\text { UAR vs. UCR }\end{array}$} & \multirow{2}{*}{ t Test } & $5 \%$ & Yes \\
\hline & & & $1 \%$ & No \\
\hline & & \multirow{2}{*}{ Wilcoxon } & $5 \%$ & Yes \\
\hline & & & $1 \%$ & No \\
\hline & \multirow{3}{*}{$\begin{array}{l}\text { UAR Pre- } \\
\text { Urban vs. Post- } \\
\text { Urban }\end{array}$} & \multirow{2}{*}{ t Test } & $5 \%$ & Yes \\
\hline & & & $1 \%$ & Yes \\
\hline & & Wilcoxon & $5 \%$ & Yes \\
\hline & \multirow{4}{*}{$\begin{array}{l}\text { UCR Pre-Urban } \\
\text { vs. Post-Urban }\end{array}$} & \multirow{2}{*}{$\mathrm{t}$ Test } & $5 \%$ & No \\
\hline & & & $1 \%$ & No \\
\hline & & \multirow{2}{*}{ Wilcoxon } & $5 \%$ & No \\
\hline & & & $1 \%$ & No \\
\hline
\end{tabular}

The comparison of the mean average warm season maximum $1-\mathrm{h}$ rainfall intensity for the different combinations of UAR, UCR, pre-urban and posturban data series suggest a possible urban effect. No difference in means is noted for the pre-urban time period between the UAR and UCR, but a statistically significant difference (UAR greater than UCR) is noted in the posturban time period at the $5 \%$ level. A statistically significant increase is noted in the maximum 1-h intensity between the pre-urban and post-urban time periods in the UAR, but no difference is found in the UCR. Similar results are observed for the mean average warm season number of heavy rainfall events. A statistically significant increase in number of warm season heavy rainfall events 
is found in the UAR compared to the UCR for the post-urban time period, while a statistically significant difference was not noted for the pre-urban time period. And the UAR pre-urban to post-urban increase in warm season heavy storm events was found to be statistically significant, whereas the changes in the UCR were not significant.

\subsection{Coupled Meteorological-Hydrologic Modeling}

The evidence of the urbanization impact on rainfall described above prompts the next step to investigate potential impacts of rainfall modification on urban drainage systems. If rainstorm characteristics are being modified and heavy rainstorms are being enhanced then the implications of these modifications must be understood within an urban hydrologic response context. To study the problem, a coupling is being developed between the Penn State/NCAR mesoscale model (MM5) and SWMM. The coupling will involve scaling the MM5 predicted rain fields to appropriate space-time levels for use in a calibrated SWMM model of the Greens Bayou watershed in Houston. Long-term rainfall time series (14+y of 15-min rainfall), standard engineering design storms (for pre-urban and post-urban time periods), and MM5-predicted rain fields will be fed into SWMM and the hydrologic response in terms of peak flow rates, timesto-peak discharges, hydrographs, runoff volumes, and flood inundation within the watershed and at the outlet will be assessed.

The linkage of the MM5 simulations to SWMM will be through the predicted rain fields. The MM5 rain fields will be gridded and aggregated to 5 -min time increments. Feeding MM5 predicted rain fields into SWMM will require the gridded MM5 precipitation fields to be scaled in space and time to correspond to the rainfall data used to calibrate the SWMM watershed model. In addition, a weighting scheme will be used to determine a rainfall series to use for each SWMM subcatchment since the subcatchments will not correspond one-to-one with the evenly-spaced gridded rain fields. A series of numerical experiments will then be performed to determine the change in hydrologic response from urban watersheds to urban-influenced convective rainfall. The following three simulation runs will be performed with MM5:

1. standard MM5 run with standard slab surface (no urban);

2. standard MM5 run with Oregon State Land Surface Classes (including urban); and

3. MM5-PLACE (non-optimized - no urban surfaces). 
Predicted rain fields will then be fed into the SWMM watershed model and the response at selected points within the watershed will be analyzed.

In addition to the continuous simulations, the design event simulations, and the MM5-SWMM linkage, SWMM simulations will also be made with the rainfall records from pre- and post-urban time periods with existing land use conditions to investigate how the modified rainfall pattern has changed the hydrologic response. The final phase will involve the derivation of updated intensity-duration-frequency relationships to determine the design storm rainfall intensities within the city for current conditions and a comparison of these intensities with those obtained by Bouvette et al. (1982) and from the National Weather Service TP-40 (Hershfield 1961). Design storms will be developed and fed into SWMM to investigate the impact of altered design storms on hydrologic response.

\subsection{Conclusions}

A downscaling analysis approach of rainfall data for Southeast Texas has been performed to identify and quantify rainfall anomalies in Houston that may be caused by the urban area. Results from the conjunctive analyses of TRMM PR conditional mean monthly rain rates and raingage records provide strong multiscale evidence that Houston is modifying rainfall patterns in and downwind of the city. Raingage data analysis found the raingages in the urban-affected regions to have statistically significant higher average annual and warm season rainfall amounts from 1984-1997. The urban area had 22\% greater rainfall during the average warm season than the upwind control region and the downwind urban-impacted region. The isolated enhanced rainfall was consistent with the TRMM PR data analysis. To further refine the urban influence on rainstorms in Houston, the raingage data were divided into independent storm events and analyzed for a relatively pre-urban time period and a post-urban time period for nine raingages. The average maximum $1-\mathrm{h}$ rainfall intensity during the warm season increased from pre- to post-urban in the urban area by $16 \%$, compared to a $4 \%$ increase in the upwind control region. Moreover, the average number of "heavy" ( $\geq 25 \mathrm{~mm}$ ) rainstorms occurring during the warm season increased by $35 \%$ in the urban-affected region from pre- to post-urban time periods, while a $3 \%$ decrease was noted in the upwind control region. Thus, the cumulative evidence provided by the TRMM PR, raingage annual and seasonal totals, and storm event characteristics indicates that the rainfall patterns are different in the urban-affected regions of Houston compared to the upwind 
control regions. The next step is to continue to validate these results by compiling and analyzing additional rainfall data and to discover what effect, if any, the rainfall modification will have on hydrologic response in cities and what the implications are for flood control and urban drainage design. The coupling of a meteorological model and SWMM is ongoing to study this issue and the results will be reported in the near future.

\section{Acknowledgments}

This research was supported by a NASA/ASEE summer faculty fellowship for the first author and a NASA New Investigator Program Award for the second author.

\section{References}

Adams, B.J. and Papa, F. (2000). Urban stormwater management planning with analytical probabilistic models. John Wiley \& Sons, Inc., New York, pp. 53-77.

Atkinson, B.W. (1968). "A preliminary investigation of the possible effect of London's urban area on the distribution of thunder rainfall, 1951-1960." Trans. Inst. Brit. Geogr., 44, 97-118.

Balling, R.C. and Brazel, S.W. (1987). "Recent changes in Pheonix, Arizona Summertime Diurnal Precipitation Patterns." Theoretical and Applied Climatology, 38, pp 50-54.

Bornstein, R.D. (1968). "Observations of the urban heat island effect in New York City." J. Appl. Meteor., 7, 575-582.

Bornstein, R. and Lin, Q. (2000). "Urban heat islands and summertime convective thunderstorms in Atlanta: three cases studies." Atm. Env., 34, 507-516.

Bouvette, T.C., Lambert, J.L., and Bedient, P.B. (1982). "Revised rainfall frequency analysis for Houston." Journal of the Hydraulics Division, ASCE, 108, 515-528.

Changnon, S.A. (1968). "The La Porte weather anomaly - fact or fiction?" Bulletin of the American Meteorological Society, 49, 4-11.

Changnon, S.A. (1980). "Summer flooding at Chicago and possible relationships to urban-increased heavy rainfall." Water Resources Bulletin, 16, 323-325.

Changnon, S.A. (1992). "Inadvertent weather modification in urban areas: Lessons for global climate change.” Bulletin American Meteorological Soc., 73, 619-627.

Changnon, S.A. (1996). "Effects of summer precipitation on urban transportation." Climatic Change, 32, 480-494.

Changnon, S.A., Huff, F.A., Schickedanz, P.T., Vogel, J.L. (1977). St. Louis precipitation anomalies and their impact. Vol. 1, METROMEX Final Summary, Illinois State Water Survey, $196 \mathrm{pp}$. 
Changnon, S.A. and Semonin, R.G. (1977). "Chicago area program: A major new atmospheric effort." Bulletin of the American Meteorological Society, 59, 153160.

Changnon, S.A. and Westcott, N.E. (2002). "Heavy rainstorms in Chicago: Increasing frequency, altered impacts, and future implications." Journal of the American Water Resources Association, 38(5), 1467-1475.

EPA. (1997). Urbanization and stream: Studies of hydrological impacts. EPA-841-R97-009, U.S. EPA Office of Water, Washington, DC.

Crooker, C.B. and Goldman, J.L. (1974). The changing climate, an analysis of rainfall and temperature for Houston-Galveston and a 13 county area, 1901-1973. Institute for Storm Research (now the Weather Research Center), Houston, TX.

Hershfield, D.M. (1961). Rainfall frequency atlas of the United States for durations from $30 \mathrm{~min}$ to $24 \mathrm{~h}$ and return periods from 1 to $100 \mathrm{y}$. Technical Paper No. 40, U.S. Weather Bureau, Dept. of Commerce, Washington, DC.

Hjemfelt, M.R. (1982). "Numerical simulation of the effects of St. Louis on mesoscale boundary layer airflow and vertical motion: Simulations of urban vs. non-urban

effects." J. Appl. Meteor., 21, 1239-1257.

Horton, R.E. (1921). "Thunderstorm breeding spots." Monthly Weather Review, 49, 193.

Huber, W.C. and Dickinson, R.E. (1988). Storm Water Management Model, Version 4, Part A: User's Manual. EPA-600-3-88-001a, U.S. Environmental Protection Agency, Athens, GA.

Huff, F.A. and Changnon, S.A. (1973). "Precipitation modification by major urban areas." Bulletin of the American Meteorological Society, 54, 1220-1232.

Huff, F.A. and Vogel, J.L. (1978). "Urban, topographic and diurnal effects on rainfall in the St. Louis Region." Journal of Applied Meteorology, 17(5), 565-577.

Jauregui, E. and Romales, E. (1996). "Urban effects on convective precipitation in Mexico City." Atmospheric Environment, 30, 3383-3389.

Kelly, T.J. (1972). "An investigation of the possible urban effects on precipitation in the Houston, Texas area." MS thesis, The University of Oklahoma, Norman, Oklahoma, $58 \mathrm{p}$.

Landsberg, H.E. (1956). "The climate of towns." Man's Role in Changing the Face of the Earth, University of Chicago Press, Chicago, 584-606.

Orville, R.E., Huffines, G., Nielsen-Gammon, J., Zhang, R., Ely, B., Steiger, S., Phillips, S., Allen, S., and Read, W. (2001). "Enhancement of cloud-to-ground lightning over Houston, Texas." Geophysical Research Letters, 28, 2597-2600.

Quattrochi, D., Luvall, J., Estes, M., Lo, C., Kidder, S., Hafner, J., Taha, H., Bornstein, R., Gillies, R., and Gallo, K. (1998). "Project Atlanta (Atlanta Land use Analysis: Temperature and Air Quality): a study of how urban landscape affects meteorology and air quality through time." Preprint Volume. Second AMS Urban Environment Conference, Albuquerque, NM, pp. 104-107.

Pitt, R.E., S. Chen, S. Clark, J. Lantrip, C.K. Ong and J. Voorhees. 2003. "Infiltration Through Compacted Urban Soils and Effects on Biofiltration Design." Journal of Water Management Modeling R215-12. doi: 10.14796/JWMM.R215-12. 
Restrepo-Posada, P.J. and Eagleson, P.S. (1982). "Identification of independent rainstorms." Journal of Hydrology, 55, 308-319.

Rozoff, C. M., Cotton, W.R., and Adegoke, J.O. (2003). "Simulation of St. Louis, MO land-use Impacts on thunderstorms." Journal of Applied Meteorology (in press).

Thielen, J., Wobrock, W., Gadian, A., Mestayer, P.G., and Creutin, J.-D. (2000). "The possible influence of urban surfaces on rainfall development: a sensitivity study in 2D in the meso-gamma scale." Atm. Res., 54, 15-39.

Scheuler, T.S. (1994). "The importance of imperviousness." Watershed Protection Techniques, 1(4), 100-111.

Shepherd, J.M. and Burian, S.J. (2003). "Detection of urban-induced rainfall anomalies in a major coastal city." Earth Interactions, 7(paper no. 4), 1-17.

Shepherd, J.M., Pierce, H.F., and Negri, A.J. (2002). "Rainfall modification by major urban areas: Observations from spaceborne rain radar on the TRMM satellite." J. Appl. Meteor., 41, 689-701. 